\title{
Real-time ultrasound-guided epidural catheter insertion in obese parturients
}

\author{
Alexandre Gnaho, MD • Antoine Nau, MD • \\ Marc Edouard Gentil, MD, PhD
}

Received: 15 December 2014 / Revised: 6 June 2015 / Accepted: 15 July 2015 / Published online: 1 August 2015

(C) Canadian Anesthesiologists' Society 2015

\section{To the Editor,}

Emerging literature suggests the usefulness of preprocedural ultrasound (US) assessment of the lumbar spine $^{1}$ to facilitate epidural catheter insertion. There are also reports of single-operator real-time US-guided epidural catheter insertion in patients with normal anatomy. ${ }^{2,3}$ Epidural catheter insertion in morbidly obese parturients can be technically challenging. ${ }^{4}$ We describe the advantage of real-time US-guided epidural insertion in this patient population after failure of a pre-procedural US of the lumbar spine followed by an attempted standard loss-of-resistance epidural technique.

Following Institutional Ethics Committee approval (CERCAR-HIAB-FARU-2009-005) and patient consent, morbidly obese (body mass index $>40 \mathrm{~kg} \cdot \mathrm{m}^{-2}$ ) parturients with failed epidural catheter insertion (more than three attempts by an experienced operator despite pre-procedural US assessment of the lumbar spine) participated in this study from May 31, 2010 to August1, 2013. With the parturient in the sitting position, one operator applied a SonoSite Edge ${ }^{\mathrm{TM}} 2-5 \mathrm{MHz}$ curved array probe (Bothell, WA, USA) over the mid-lumbar spine to obtain a scan of the paramedian oblique sagittal plane. ${ }^{1}$ During real-time US guidance, a second operator carefully advanced a $17 \mathrm{G}$ Tuohy needle (Vygon, France) into the interlaminar space until the needle tip reached the posterior part of the ligamentum flavum-dura mater complex. In cases where the tip was not visible, a slight jiggling of the needle to move the tissues helped localize its position. With the probe held firmly against the patient's back, the needlesyringe ( $5 \mathrm{~mL}$ saline) assembly was carefully advanced in a standard manner using the loss of resistance technique. Epidural anesthesia was obtained with sufentanyl $10 \mu \mathrm{g}$ and $0.1 \%$, ropivacaine $15 \mathrm{~mL}$ (patient's height $<165 \mathrm{~cm}$ ) or $20 \mathrm{~mL}$. After $30 \mathrm{~min}$, the level of sensory block (cold perception), motor block (Bromage scale), and patient satisfaction score $(1=$ best to $6=$ worst $)$ were assessed.

Real-time US-guided epidural catheters were successfully inserted in all patients who took part in this project (Table). The epidural space was identified using one to three attempts. The tip of Tuohy needle was not visible in four cases, and we were able to identify the catheter in only $1 / 10$ parturients. No inadvertent dural puncture occurred, and recovery from epidural analgesia was uneventful in all parturients.

We report real-time US-guided epidural catheter insertion in morbidly obese patients. This technique may be useful in cases where patient anatomy presents difficult epidural catheter insertion. Further studies are warranted to assess safety and efficacy of such a strategy. 
Table 1 Parturient demographics and study data

\begin{tabular}{|c|c|c|c|c|c|c|c|}
\hline Patient \# & Age (yr) & $\begin{array}{l}\text { Sensory level } \\
\text { (left/right) }\end{array}$ & $\begin{array}{l}\text { Bromage score } \\
\text { (left/right) }\end{array}$ & $\begin{array}{l}\text { BMI } \\
\left(\mathrm{kg} \cdot \mathrm{m}^{-2}\right)\end{array}$ & $\begin{array}{l}\text { Number of } \\
\text { attempts }\end{array}$ & $\begin{array}{l}\text { Satisfaction } \\
\text { score } 1=\text { best } \\
\text { to } 6=\text { worst }\end{array}$ & Modification of ES at LOR \\
\hline 1 & 32 & $\mathrm{~T} 10 / \mathrm{T} 10$ & $2 / 2$ & 40.4 & 2 & 2 & $\begin{array}{l}\text { Anterior displacement of posterior } \\
\text { dura and widening of ES }\end{array}$ \\
\hline 2 & 27 & $\mathrm{~T} 8 / \mathrm{T} 10$ & $3 / 2$ & 41.2 & 2 & 3 & None \\
\hline 3 & 30 & $\mathrm{~T} 10 / \mathrm{T} 12$ & $2 / 2$ & 41.0 & 2 & 2 & $\begin{array}{l}\text { Anterior displacement of posterior } \\
\text { dura and widening of ES }\end{array}$ \\
\hline 4 & 28 & $\mathrm{~T} 10 / \mathrm{T} 10$ & $2 / 2$ & 41.5 & 2 & 1 & None \\
\hline 5 & 39 & $\mathrm{~T} 10 / \mathrm{T} 10$ & $2 / 2$ & 41.1 & 3 & 1 & $\begin{array}{l}\text { Anterior displacement of posterior } \\
\text { dura and widening of ES }\end{array}$ \\
\hline 6 & 30 & $\mathrm{~T} 12 / \mathrm{T} 10$ & $2 / 3$ & 42.8 & 3 & 2 & None \\
\hline 7 & 33 & $\mathrm{~T} 10 / \mathrm{T} 10$ & $2 / 2$ & 42.0 & 2 & 3 & $\begin{array}{l}\text { Anterior displacement of posterior } \\
\text { dura and widening of ES }\end{array}$ \\
\hline 8 & 31 & $\mathrm{~T} 10 / \mathrm{T} 12$ & $3 / 2$ & 40.6 & 2 & 1 & $\begin{array}{l}\text { Anterior displacement of posterior } \\
\text { dura and widening of ES }\end{array}$ \\
\hline 9 & 30 & $\mathrm{~T} 12 / 10$ & $2 / 2$ & 40.5 & 2 & 2 & $\begin{array}{l}\text { Anterior displacement of posterior } \\
\text { dura and widening of ES }\end{array}$ \\
\hline 10 & 29 & $\mathrm{~T} 10 / \mathrm{T} 10$ & $2 / 2$ & 41.8 & 2 & 2 & None \\
\hline
\end{tabular}

$\mathrm{BMI}=$ body mass index; $\mathrm{ES}=$ epidural space; LOR = loss of resistance

Conflicts of interest None declared.

\section{References}

1. Tran D, Kamani AA, Lessoway VA, Peterson C, Hor KW, Rohling $R N$. Preinsertion paramedian ultrasound guidance for epidural anesthesia. Anesth Analg 2009; 109: 661-7.
2. Karmakar MK, Li X, Ho AM, Kwok WH, Chui PT. Real-time ultrasound-guided paramedian epidural access: evaluation of a novel in-plane technique. Br J Anaesth 2009; 102: 845-54.

3. Tran D, Kamani AA, Al-Attas E, Lessoway VA, Massey S, Rohling $R N$. Single-operator real-time ultrasound-guidance to aim and insert a lumbar epidural needle. Can J Anesth 2010; 57: 313-21.

4. Saravanakumar K, Rao SG, Cooper GM. Obesity and obstetric anaesthesia. Anaesthesia 2006; 61: 36-48. 